\title{
位相共役鏡を用いた高出力高品位バナデートレーザー
}

\author{
尾松 孝茂 1,2 , 縄田 耕二 1 \\ 1 千葉大学大学院 融合科学研究科 ( $2263-8522$ 千葉市稲毛区弥生町1-33) \\ 2科学技術振興機構
}

\section{High Power, High Quality Phase Conjugate Vanadate Lasers}

\author{
Takashige OMATSU ${ }^{1,2}$ and Kouji NAWATA ${ }^{1}$ \\ ${ }^{I}$ Graduate School of Advanced Integration Science, Chiba University, 1-33 Yayoi-cho, Inage-ku, Chiba 263-852 \\ ${ }^{2}$ PRESTO, JST
}

(Received September 18, 2007)

\begin{abstract}
We presented high quality, high power pico-second output from a diode-side-pumped $\mathrm{Nd}: \mathrm{YVO}_{4}$ laser system with a photorefractive phase conjugate mirror. Peak output powers in the range of 2.8-6.8 MW were achieved at a pulse repetition frequency range of $0.33-1.0 \mathrm{MHz}$. The corresponding average powers of $18-26 \mathrm{~W}$ were obtained.
\end{abstract}

Key Words: Laser, Laser amplifier, Phase conjugation, Nonlinear optics, Ultrafast optics

1. はじめに

アブレーション加工に十分な高いピークパワーと熱伝 導時間より短いレーザー照射時間を達成できる超短パル スレーザーは, 金属, 半導体の超精細加工から, ガラス 材料の三次元加工まで, 従来のレーザーでは困難だった 多様な加工を可能にする ${ }^{1)}$. 超短パルスレーザーの代表と してフェムト秒チタンサファイアレーザーが挙げられる が, 励起波長である青緑域で発振する高出力半導体レー ザーが存在しないため, 電力一光変換効率は, $1 \%$ に満 たない.このフォトンコストの高さが産業用途への普及 を妨げる大きな障壁となっていることは否めない.

$808 \mathrm{~nm}$, あるいは, $980 \mathrm{~nm}$ 帯の高出力半導体レーザー を励起光として用いることができる $\mathrm{Nd}$ 系, $\mathrm{Yb}$ 系固体レー ザー(半導体レーザー励起固体レーザー) は，パルス幅こそ ピコ秒からサブピコ秒とチタンサファイアレーザーには 及ばないものの電力一光变換効率は圧倒的に高く $10 \% に$ 迫る．産業用加工の多くの場面ではピコ秒パルスでも十 分な加工性能が得られるため, 半導体レーザー励起固体 レーザーベースの高出力で高品位な超短パルスレーザー が実用になれば, 超短パルスレーザーのフォトンコスト を低減できるとともに, 大きな省エネルギー効果が期待 できる、 $\mathrm{Nd}$ 系レーザーは，Yb系レーザーに比べ大きな レーザー利得が容易に得られ, 発振しきい值も低くシス テム設計しやすい. また, 最短パルス幅こそYb系レー ザーに及ばないが, 分散補償などの光学部品を一切必要 としないNd系レーザーは, システムのコスト削減に適し ている.

一般に, 半導体レーザー励起固体レーザーでは, 励起
光である半導体レーザー光子とレーザー光子のエネル ギー差(量子欠損)などの熱負荷が原因となって熱レンズ効 果2)をはじめとする熱光学効果がレーザー光の空間モード 劣化, レーザー出力低下, 偏光度の低下を引き起こす. 例えば，代表的な固体レーザー結晶であるNd:YAG結晶を $20 \mathrm{~W}$ クスの $808 \mathrm{~nm}$ 帯半導体レーザーで端面励起した場 合, 熱レンズの焦点距離は5 $\mathrm{cm}$ 以下になる3).レーザー結 晶の熱光学効果の補償は良好なビーム品質, 高出力をめ ざすレーザー設計において最重要課題と言える。

Zel'dovichらによって, 非線形光学現象の一つである位 相共役波発生 ${ }^{4)}$ が発見されて35年の年月を数える4).これ までに，位相共役波の位相補償性を利用した数多くのCW やナノ秒パルスレーザーが報告されてきた5-7). しかしな がら, 超短パルス光に対して位相共役波を発生させる素 子位相共役鏡 (PCM：Phase conjugate mirror)がない, 一般 に位相共役鏡の損傷しきい值は低いので大きなレーザー 出力は得られない, という二つの大きな先入観のために 超短パルス高出力レーザーを開発することは不可能であ ると考えられてきた。

われわれは，位相共役鏡が示すスペクトル狭窄効果を 抑制すること，1000倍を越えるレーザー利得を示す側面 励起イットリウムバナデート $\left(\mathrm{Nd}: \mathrm{YVO}_{4}\right)$ スラブ増幅器を 用いて位相共役鏡の損傷を避けること, の二つのブレー クスルーによって, 高い平均出力 $(>25 \mathrm{~W})$, 高いピーク パワー(>2 MW), 高い繰返し周波数 (> $100 \mathrm{kHz})$, 高い ビーム品質を誇るピコ秒パルス位相共役レーザーシステ ムを世界ではじめて開発した8,9).

高出力超短パルスレーザーで一般的に用いられている 再生増幅器方式 10,11$)$ とは異なり, 単純なレーザー発振器一 
増幅器 (MOPA : Master-Oscillator Power Amplifier) からなる 本システムでは, 再生増幅器に比べ杕違いに速いパルス の繰返し動作が可能になるので, 高い平均出力と高い ピークパワーを容易に両立できる。

\section{2. 固体レーザー素子に誘起される熱効果}

固体レーザー結晶中では，光子エネルギーの量子欠損 の他，レーザー上準位の無輻射緩和，レーザー上準位か らのアップコンバージョン遷移などのさまざまな要因か ら熱が発生する12)。この熱が結晶の膨張や屈折率変化を 誘起して熱レンズなどの熱光学効果を引き起こす. Fig. 1 は， $\mathrm{Nd}: \mathrm{YVO}_{4}$ 結晶を $20 \mathrm{~W}$ 半導体レーザーアレイで側面励 起した場合の結晶温度分布を計算したものである。観測 される温度上昇は最大で40度を超え，熱レンズの焦点距 離に換算するとおおよそ $3 \mathrm{~cm}$ になる13)．高励起時には，こ の強いレンズ効果に加え各種収差も複合的に現れるの で，普通の光学系を用いて熱効果を完全に補償し，レー ザーを安定に動作させることは極めて難しい.

\section{3. 実 験}

\section{1 超短パルスレーザーのための位相共役鏡}

PCMは入射した波面の空間反転(あるいは時間反転)さ せた光波面，位相共役波を発生する素子である，PCMを

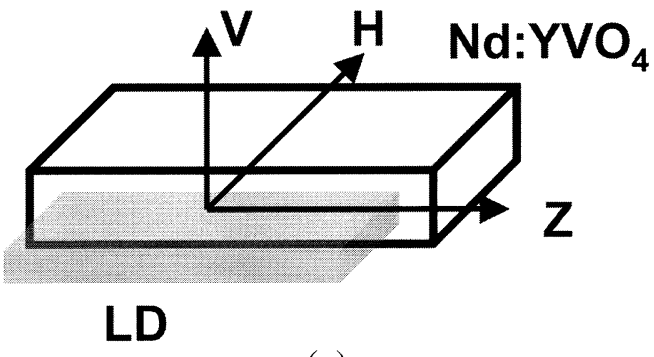

(a)

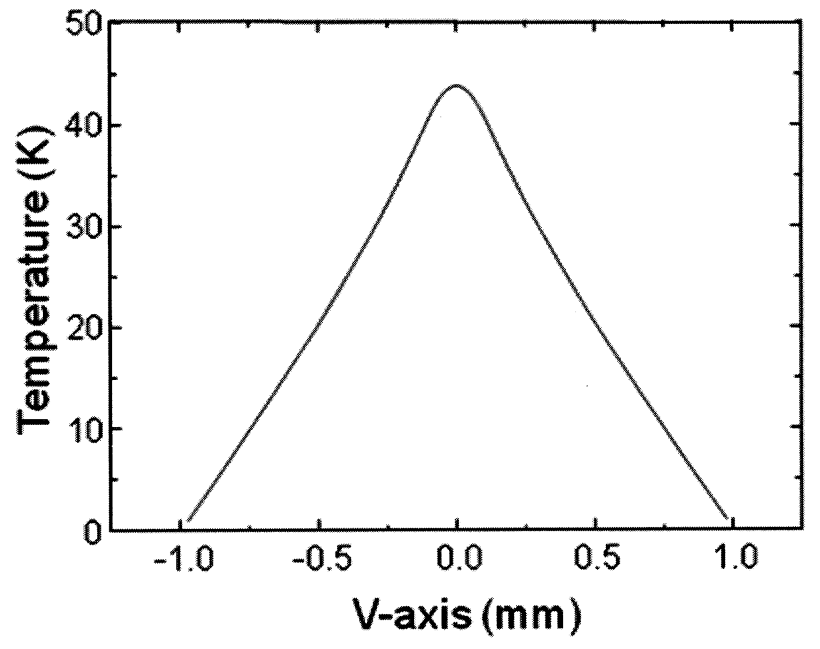

(b)

Fig. 1 (a) Schematic diagram of side-pumping geometry, and (b) simulated temperature distribution in the $\mathrm{Nd}: \mathrm{YVO}_{4}$ slab amplifier.
MOPAシステムの一部に配置すると, 増幅器を通過したマ スターレーザー光が位相共役波として増幅器に再び戻る 間に増幅器内部で受けた熱光学効果が自動的に補償され てビーム品質の高い増幅光が取り出せる。このようなシ ステムをPC-MOPAと呼ぶことにする．従来，CWやナノ 秒パルスに対するPC-MOPAはこれまでに数多く報告され ているが，ピコ秒パルスに対しては，われわれの研究を 除き報告例がない。その一つは位相共役鏡によるレー ザースペクトルの狭窄化効果にある。フォトリフラク ティブ効果を用いた位相共役波発生の起源は，結晶内に 形成された屈折率回折格子による入射光の Bragg回折であ る. 結合波方程式に従うと屈折率回折格子のBragg回折に よる波長許容幅 $\Delta \lambda$ は

$$
\Delta \lambda=\frac{2 \kappa \Lambda^{2} n_{0} \cos \theta_{B}}{\pi}
$$

と書ける14).ここで， $\kappa$ は二光波混合結合係数， $\Lambda$ は屈折 率格子の格子間隔， $n_{0}$ は $\mathrm{BaTiO}_{3}$ 結晶の屈折率， $\theta_{B}$ は屈折率 格子を形成する二光束のなす角度の半角である，波長許 容幅 $\Delta \lambda$ は屈折率格子の格子間隔 $\Lambda$ に強く依存することが 分かる. 反射型や $2 k$ 型と呼ばれる格子間隔 $\Lambda$ の狭い屈折率 回折格子は波長許容幅が極端に狭くなり強い波長選択性 を示すので，発生される位相共役波のスペクトルは狭窄 化される。この現象は，位相共役波のフィードバックを 受けた半導体レーザーなどで顕著に見られ，一般に，位 相共役波のスペクトルは<0.2 nmになる15).

われわれは反射型， $2 k$ 型回折格子の形成を抑えて位相共 役鏡によるスペクトル狭窄を回避するために，リング型 位相共役鏡を用いた (Fig. 2).

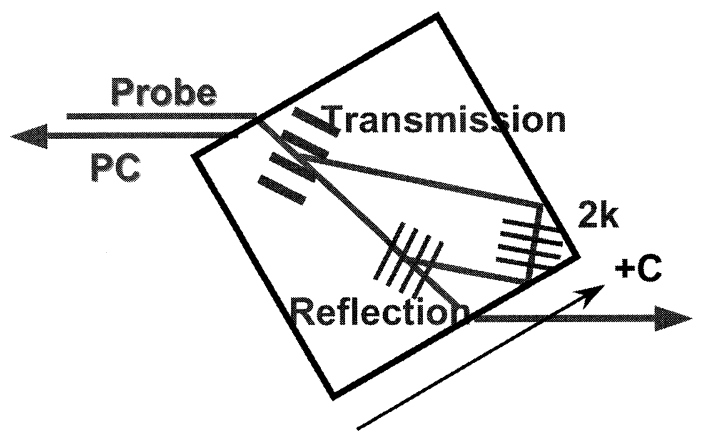

(a)

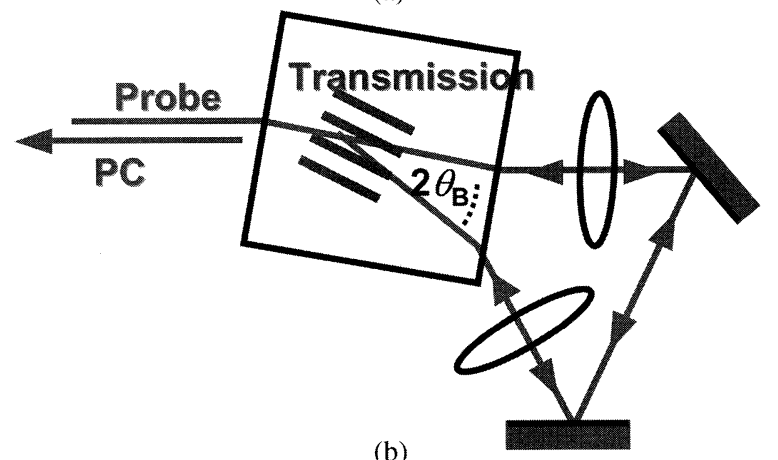

(b)

Fig. 2 (a) Total internal reflection (TIR) phase conjugate mirror. (b) Self-pumped ring phase conjugate mirror. Formation of reflection as well as $2 k$ gratings is inhibited. 
また，リング型共振器の頂角を小さくして透過型回折 格子の格子間隔を広げ，位相共役鏡の波長許容幅を可能

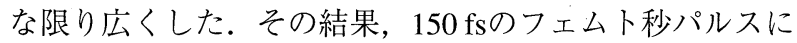
対しても，50\%程度の高い位相共役波反射率を確認でき た(Fig. 3).

\section{2 側面励起バナデートレーザー増幅器}

側面励起バナデート増幅器はBernardらによって1993年に 初めて報告がなされた16). $\mathrm{Nd}$ ドープバナデートは $808 \mathrm{~nm}$ 半 導体レーザー光に対して強い吸収を示すため, スラブ結晶 側面近傍に反転分布密度の高い部分ができる17,18)。この部 分を通過するレーザー光はバナデートの示す強い誘導放 出によって大きなレーザー増幅を経験する。おおよそ 20-30 Wの励起時に，スラブ型バナデート結晶を一度通 過するだけで，100倍を超える増幅率が容易に得られる (Fig. 4).

実際のシステム図をFig. 5に示す。増幅器に用いた結晶 はNdイオン濃度 1 at. \%, a-カット Nd: $\mathrm{YVO}_{4}$ スラブでサイズ は20 mm $\times 5 \mathrm{~mm} \times 2 \mathrm{~mm}$ である。結晶の両端面は結晶内部 での寄生発振を抑制するために，励起面鉛直方向に対し て 5 度傾いている. 励起半導体レーザーはダイオードアレ イスタックで発振波長 $808 \mathrm{~nm}$, 最大出力は $135 \mathrm{~W}$ あ゙あ. 各アレイから出た光はシリンドリカルレンズ (CLD)で増 幅器励起面に直線状に集光されている．励起光の集光 ビームサイズはおおよそ $0.3 \mathrm{~mm} \times 18 \mathrm{~mm}$ である。 マスター

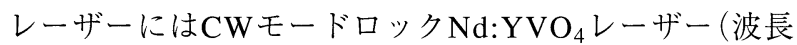
$1064 \mathrm{~nm}$, 最大出力 $250 \mathrm{~mW}$ ，パルス幅7 ps, 繰返し周波数 (PRF) $100 \mathrm{MHz}$ )を用いた。 マスターレーザーのPRFはRTP 結晶からなるポッケルスセルによって $330 \mathrm{kHz}-1 \mathrm{MHz}$ の間 で可変である。この場合, ポッケルスセル通過後のマス ターレーザー出力は<2 mWになる. $\mathrm{Nd}: \mathrm{YVO}_{4}$ 増幅器の楕 円形をしている励起領域と効率よく結合するようにマス ターレーザー光は2枚のシリンドリカルレンズ $\left(\mathrm{HCL}_{1}\right.$,

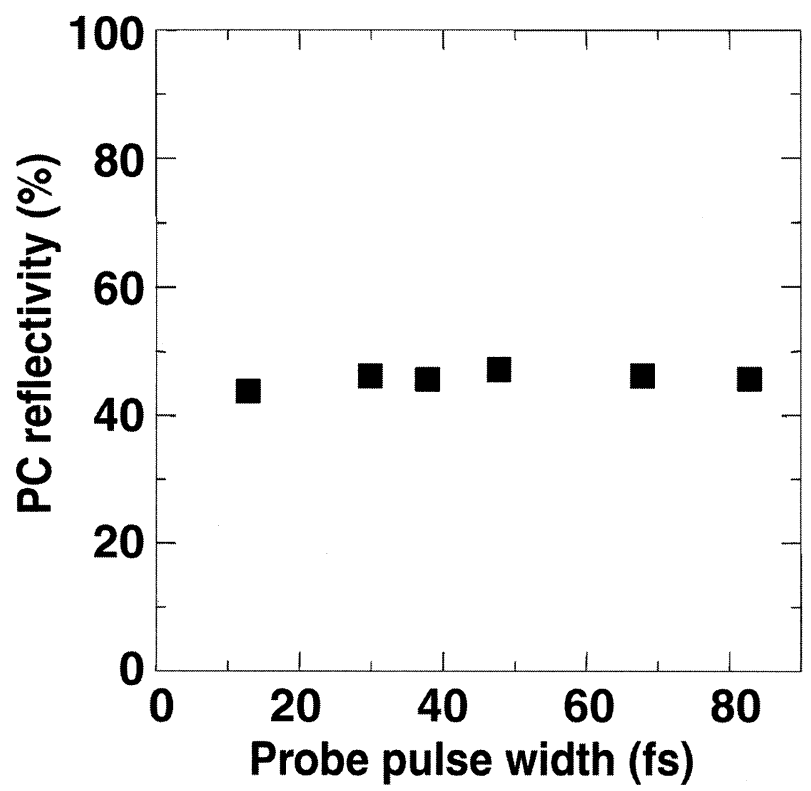

Fig. 3 Experimental phase conjugate reflectivity as a function of probe pulse width.

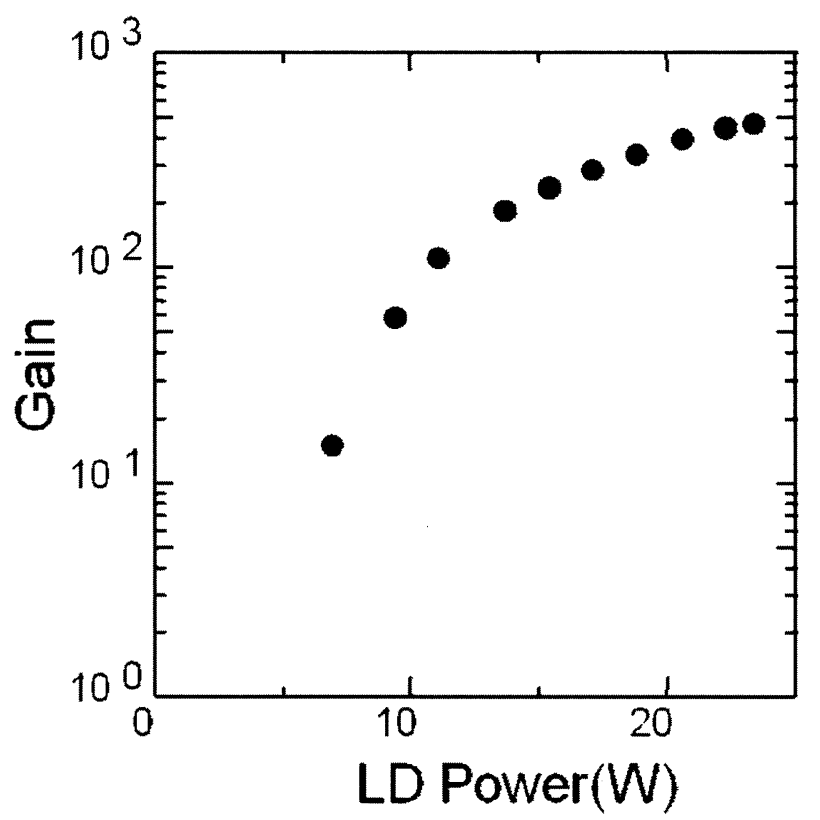

Fig. 4 Experimental single-pass gain in the $\mathrm{Nd}: \mathrm{YVO}_{4}$ slab amplifier.

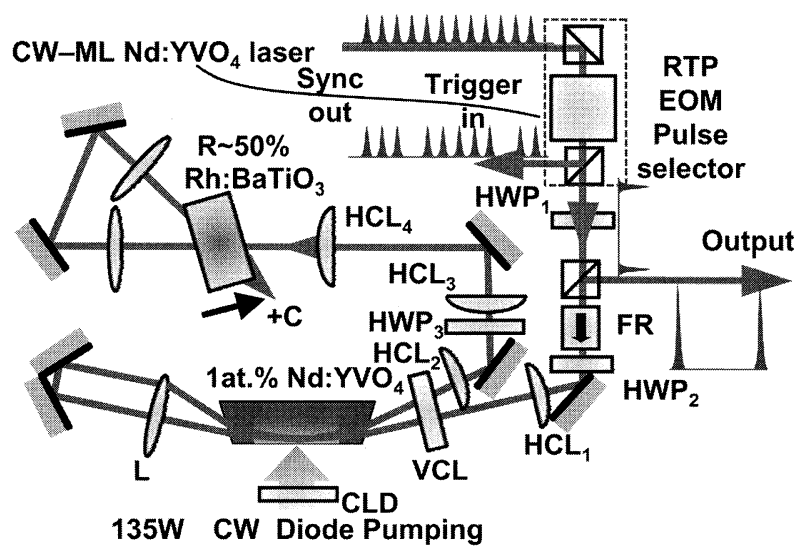

Fig. 5 Experimental setup.

VCL)で楕円形に整形されている。増幅器から出たマス ターレーザー光は, レンズ，プリズムからなる等倍の結 像光学系を介して再び増幅器に戻り, さらに増幅され位 相共役鏡へと伝播する。

位相共役鏡には， $\mathrm{Rh}$ イオンドープ $\mathrm{BaTiO}_{3}$ 結晶 $(\mathrm{Rh}$ イオ ン濃度 $1000 \mathrm{ppm}, 8 \mathrm{~mm} \times 7 \mathrm{~mm} \times 6 \mathrm{~mm})$ を用いた。結晶 の外部に配置したリング共振器の頂角は〜 15度である. 光吸収に伴う $\mathrm{BaTiO}_{3}$ 結晶の温度上昇を抑制するため, $\mathrm{BaTiO}_{3}$ 結晶は水冷されたアルミ製ホルダーにマウントさ れている.

マスターレーザー光が入射後，1-2分で位相共役鏡は立 ち上がり，その反射率は50\%になる。増幅されたマス ターレーザー光の位相共役波は再び増幅器に戻り，偏光 ビームスプリッター(PBS)より出力される。したがって, マスターレーザー光は都合4 回 $\mathrm{Nd}: \mathrm{YVO}_{4}$ レーザー増幅器を 通過することになり, 増幅器の利得は数 $\mathrm{mW}$ 程度のわずか な入力パワーで十分飽和させることができる. 


\section{3 実験結果}

まず，ポッケルスセルをオフにしてPRFは100 MHzで実 験を行った。励起パワーに対するレーザー出力をFig. 6に 示す。パルスレーザー出力は励起パワーにほぼ比例して 増大し, 最大励起パワー時 $(80 \mathrm{~W})$ に $25 \mathrm{~W}$ に達した。光一 光変換効率は $30 \%$ を超える。マスターレーザーから見た 増幅率は 100 倍を超えるので，実際に位相共役鏡に入射し ているレーザー光のパワーは $2 \mathrm{~W}\left(\sim 100 \mathrm{~W} / \mathrm{cm}^{2}\right)$ 程度であ る。位相共役鏡の光損傷しきい值 $\left(<1 \mathrm{~kW} / \mathrm{cm}^{2}\right)$ より入射光 強度は十分小さいので，位相共役鏡の光損傷なくさらな るパワースケーリングは可能である19).

引き続いてポッケルスセルをオンにし，PRFを1 MHzに した。この場合，システムに入射しているマスターレー ザー光は〜 $2 \mathrm{~mW}$ あ゙ある、マスターレーザー入力が $1 / 100 に$ 低下しているにもかかわらず，励起パワー最大時のレー ザー出力 $(26.3 \mathrm{~W})$ はほとんど変化しないことがわかる。ま た，オートコリレーション波形(Fig. 7)から換算したパル ス幅 $(8 \mathrm{ps})$ と増幅光パルスのコントラスト比 $(600: 1)$ を用い てピークパワーに換算すると，2.8 MWに達した。

次に励起パワーを $80 \mathrm{~W} に$ 固定したままさらにPRFを変え てレーザー出力を測定した．PRFが小さくなるにつれて レーザー出力は若干低下するが，PRFが330 kHzでも20 W 近い平均出力が得られる。パルス幅, パルスコントラス ト比から換算するとピークパワーは6.8 MWに達する。こ れらの結果は，前述したようにNd: $\mathrm{YVO}_{4}$ 増幅器の利得が 大きく $\mathrm{mW}$ 程度の微弱な入力で十分利得が飽和できること による。

図中の破線は，CW時の飽和増幅に対して用いられる
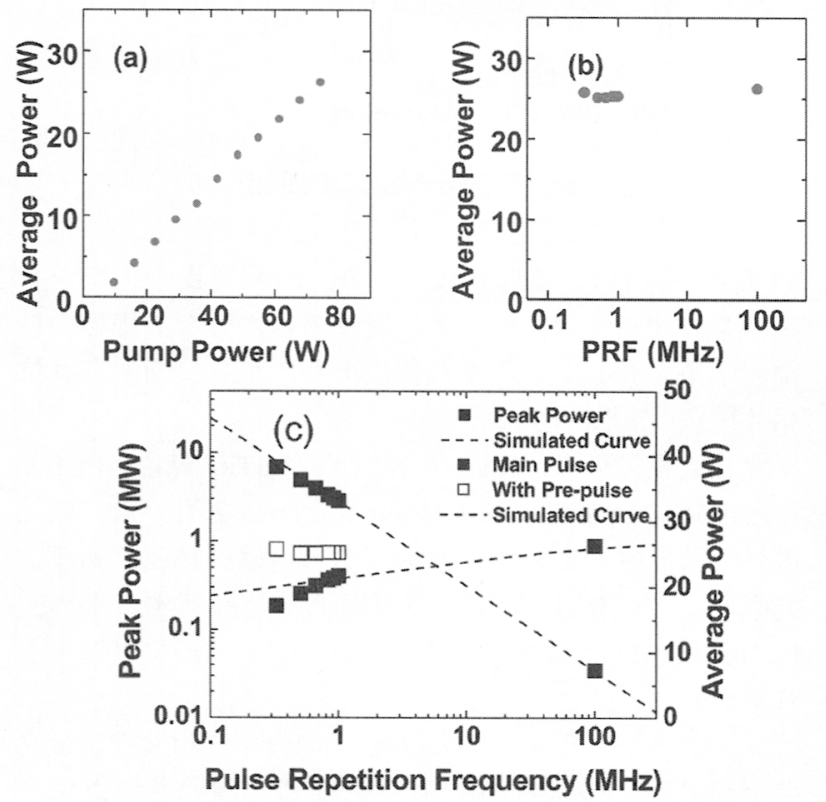

Fig. 6 (a) Plot of average output power as a function of pump power at a PRF of $100 \mathrm{MHz}$. (b) Average output power for various PRFs. (c) Estimated peak power as a function of PRF. The dashed lines show the simulated values calculated on the basis of the continuous-wave gain saturation and the partitioned gain models.
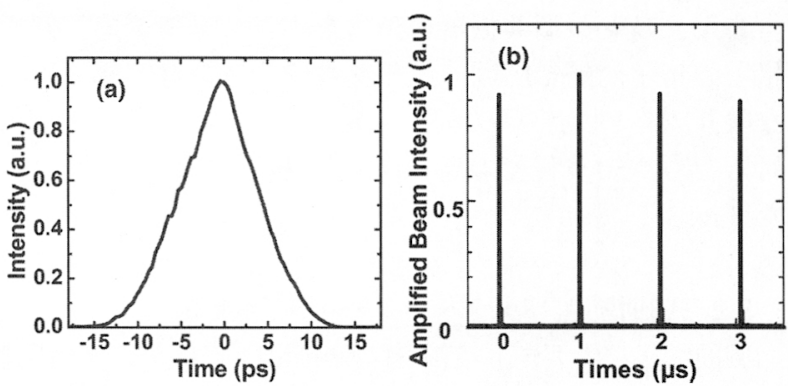

Fig. 7 (a) Auto-correlation trace of the amplified output. (b) Temporal evolution of amplified output. Measured contrast ratio of prepulses to main pulses is $\sim 1: 600$.

$$
g(I)=\frac{g_{0}}{1+I / I_{S}}
$$

を仮定して，相互作用する光波の数で利得領域を領域分 割したモデルにより数值計算した結果である20,21)。ここ で, $g_{0}$ は小信号利得, $I$ は増幅器へ入射する光強度, $I_{s}$ $\left(\sim 1 \mathrm{~kW} / \mathrm{cm}^{2}\right)$ は利得飽和強度である。実験值と良い整合 が得られている。

空間モードはFig. 8に示すように良好であり， $M^{2}$ 值に換 算して<1.5である。こ㞦に対して位相共役鏡に入射する直 前の増幅されたマスターレーザー光のビーム品質は $M^{2}$ 值 で〜4であることから，位相共役鏡がレーザー増幅器の熱 収差を十分に補償していることがわかる。

現状では， $\mathrm{Nd}: \mathrm{YVO}_{4}$ 増幅器を冷却するために使用して いるチラーの冷却能力と結晶マウントからの放熱の問題 で励起パワーは80-90 Wで制限されているが，冷却ユニッ トの改善によって使用している半導体レーザーの最大出 力まで励起することは十分可能である.

\section{4. まとめ}

位相共役鏡を用いた高出力ピコ秒レーザーシステムを開 発した。最大平均出力は $25 \mathrm{~W}$, 最高ピークパワーは6.8 MW である. 光一光変換効率は $30 \%$ を超える. 出力ビームの品

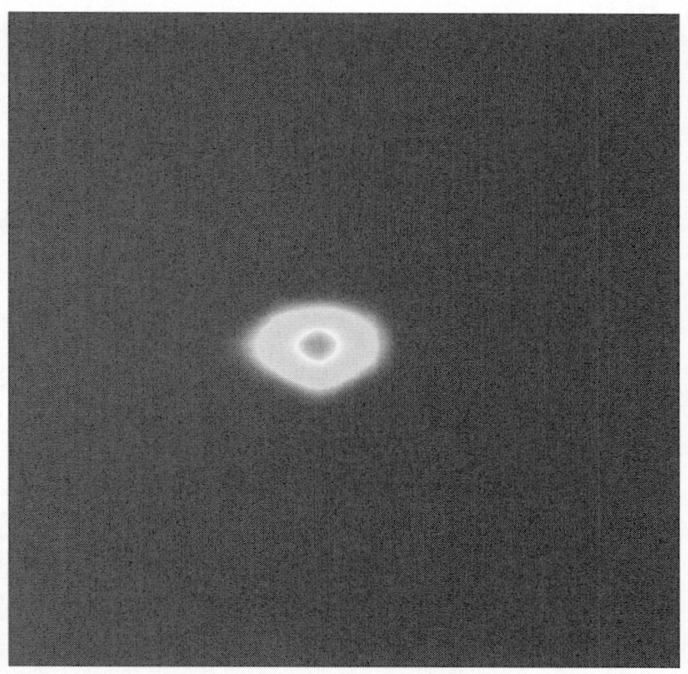

Fig. 8 Far-field pattern of the amplified output laser.

レーザー研究 2008 年 5 月 


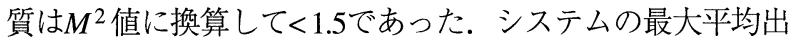

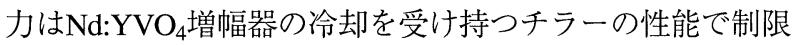
されているが, 冷却系の改善によって励起半導体レーザー の最大出力まで励起できれば， $40 \mathrm{Wを}$ 超えるスケーリング は可能である. 今回の実験では, 入手しやすい $808 \mathrm{~nm}$ 帯半 導体レーザーを励起光に用いたが， Ndイオンをレーザー上 準位に直接励起できる $880 \mathrm{~nm}$ 帯半導体レーザーを用いれ ば，熱負荷が軽減できるのでパワースケーリングも容易に なる. また, 光一光変換効率も向上するので, さらなる省 エネルギー効果が期待できる.

われわれが開発したレーザーシステムは一般に良く用 いられている再生増幅器とは異なり, 高利得増幅器と位 相共役鏡だけで構成されている単純なMOPAシステムであ る.したがって，パルス繰返し周波数はポッケルスセル のスイッチング速度だけで決まり，100 kHzを超える高い 繰返し動作が可能である. $100 \mathrm{kHz}$ を超える高い繰返し周 波数とMWを超える高いピークパワーを兼称備えた本レー ザーシステムを用いれば，スループットの高い超高速微 細加工が可能になる.

パルス幅がピコ秒〜フェムト秒の超短パルスレーザー は潜在的に幅広い灾用が期待されているが，高いフォト ンコストが普及の大きな障害となっている。パワース ケーリングの容易な高出力ピコ秒レーザーは超短パルス 光のフォトンコストを大幅に下げ，超短パルスレーザー の潜在的市場を掘り起こす起爆剤になる可能がある.

\section{参考文献}

1) B. N. Chichkov, C. Momma, S. Nolte, F. von Alvensleben, and A. Tunnermann: Appl. Phys. A 63 (1996) 109.

2) W. Koechner: Solid-state laser engineering $4^{\text {th }}$ ed (Springer, 1995).

3) J. L. Blows, J. M. Dawes, and T. Omatsu: J. Appl. Phys. 83 (1998) 2901.

4) B. Ya. Zel'dovich, V. I. Popovichev, V. V. Ragul'skii, and F. S. Faizullov: Sov. Phys. JEPT Lett. 15 (1972) 109.

5) K. Tei, F. Matsumoto, M. Kato, Y. Maruyama, and T. Arisawa: Opt. Lett. 25 (2000) 481.

6) A. Brignon, J.-P. Huignard, M. H. Garrett, and I. Mnushkina: Opt. Lett. 22 (1997) 442.

7) T. Omatsu and M. J. Damzen: Opt. Commun. 198 (2001) 135.

8) T. Imaizumi, M. Goto, Y. Ojima, and T. Omatsu: Jpn. J. Appl. Phys. 43 (2004) 2515.

9) K. Nawata, M. Okida, K. Furuki, and T. Omatsu: Opt. Express 15 (2007) 9123.

10) C. Stolzenburg and A. Giesen: Proc. Advanced Solid-State Photonics (ASSP) (2007) paper MA6.

11) F. Röser, D. Schimpf, O. Schmidt, B. Ortaç, K. Rademaker, J. Limpert, and A. Tünnermann: Opt. Lett. 32 (2007) 2230.

12) J. L. Blows, T. Omatsu, J. Dawes, H. Pask, and M. Tateda: Photon. Tech. Lett. 10 (1998) 1727.

13) S. A. Amarande and M. J. Damzen: Opt. Commun. 265 (2006) 306.

14) P. Yeh: Introduction of photorefractive nonlinear optics (Wiley, 1993).

15) K. Vahala, K. Kyuma, A. Yariv, S. Kwong, M. Cronin-Colomb, and K. Y. Lau: Appl. Phys. Lett. 49 (1986) 1563.

16) J. E. Bernard and A. J. Alcock: Opt. Lett. 18 (1993) 968.

17) M. J. Damzen, M. Trew, E. Rosas, and G. J. Crofts: Opt. Commun. 196 (2001) 237.

18) A. Minassian and M. J. Damzen: Opt. Commun. 230 (2004) 191.

19) L. Lombard, A. Brignon, J. P. Huignard, E. Lallier, G. Lucas-Leclin, P. Georges, G. Pauliat, and G. Roosen: Opt. Lett. 29 (2004) 989.

20) A. Yariv: Optical Electronics $4^{\text {th }} E d$. (Saunders, 1991); R. Fisher: Optical phase conjugation (Academic, 1983).

21) Y. Ojima, K. Nawata, and T. Omatsu: Opt. Express 13 (2005) 8933. 